\title{
STUDIES ON MUNICIPAL SOLID WASTES DUMPING ON SOIL ANIONS, CATIONS AND SELECTED ENZYMES ACTIVITIES AT NJOKU SAWMILL WASTE DUMPSITE, OWERRI MUNICIPAL, IMO STATE, NIGERIA \\ *CHINYERE, G.C., OBISIKE, E.S., UGBOGU, A.E. and OSUOCHA, K.U. http://dx.doi.org/10.4314/ejesm.v6i6.8S
}

Received 23rd July 2013; accepted 5th November 2013

\begin{abstract}
In this study, the physicochemical parameters, anions, exchangeable cations, tracemetals concentrations and selected soil enzymes activities of Njoku solid waste dumpsite Owerri municipal, Nigeria were investigated. Soil temperature $\left(28.8 \pm 0.04-33.9 \pm 0.01^{\circ} \mathrm{C}\right), \mathrm{pH}$ of the heavily polluted points $(7.3 \pm 0.01-$ $7.4 \pm 0.03)$ moisture content $(26.74 \pm 0.10)$ were significantly higher $(P<0.05)$ compared to control soil samples. Similarly dumpsite soil nitrate level, percentage organic carbon, organic matter, sulphate and phosphate ions were significantly $(P<0.05)$ increased with increased waste dumping. All the exchangeable cations and trace metals concentrations investigated were higher $(P<0.05)$ than control levels. However, while the dumpsite soil alkaline phosphatase enzyme activity remained unaffected by waste dumping ( $p>0.05)$, acid phosphatase, dehydrogenase, lipase, hydrogen peroxidase and urease enzymes activities were enhanced $(p<0.05)$ at the heavily polluted points of the dumpsite compared to control samples. Although the dumping of solid wastes increased the soil nutrients, most were made unavailable to plants and microorganisms.
\end{abstract}

Keywords: Solid wastes, soil, anions, cations enzymes activities.

\section{Introduction}

Wastes are broadly classified into municipal solid waste (MSW), industrial waste and biodegradable waste. Municipal solid wastes (MSW) also called Urban Solid Wastes include predominantly household wastes (domestic wastes) and sometimes commercial wastes collected by a municipality within a given area (Ray, 2006). They are either solid or semi solid forms and generally exclude industrial hazardous wastes. The term residual wastes relates to waste left from household sources containing materials that have not been separated out or sent for processing. Biodegradable wastes can be commonly found in municipal solid wastes (MSW) as green wastes, food wastes, paper wastes, biodegradable plastics and slaughter house wastes. They are wastes typically originating from plant and animal sources which may be broken down by living organisms (Bandick et al., 1999). Although household wastes do not usually contain such large amounts of germs and excreta, they however affect public health by attracting flies, mosquitoes, rats and allowing them to breed (Torstensous et al., 1998). Soil enzymes are important for catalyzing innumerable reactions necessary for life processes of micro-organisms in soils, decomposition of organic residues, cycling of nutrients and formation of organic matter and soil structure (Dick et al., 1994). Although enzymes are primarily of microbial origin, it can also originate from plants and animal sources. These enzymes are constantly being synthesized, accumulated, inactivated and or decomposed in the soil (Dick et al., 1997, Tabatabai, 1994). The measurement of soil enzymes can be used as an indicator of the biological activities or biochemical process taking place in the soil (Tabatabai, 1994). Soil enzymes help in the biochemical transformations of pollutants in the soil and also function as a measure of soil fertility (Khaziyev and Guike, 1994). The activities of soil enzymes are reduced or inhibited when the 
concentration of pollutants in the soil are high. The activities of soil enzymes are reduced or inhibited when the concentration of pollutants in the soil are high (Makoi and Ndakidemi, 2008) These soil enzymes and microorganisms not only play an active role in soil fertility as a result of their involvement in the cycle of nutrients required for plant growth but also serve as sensitive biological indicators. The environmental consequences of wastes pollutions include the adverse effect on soil physicochemical parameters (which assist in soil fertility and the productive ability of arable crops) and enzyme activities (Dick, 1997). Soil microorganisms play significant roles in soil fertility, as they are associated with the transformations and degradations of waste materials and synthetic organic compounds (Torstensous et al., 1998). Biodegradation of waste as a natural process may proceed slowly depending on the type of pollutant. Njoku sawmill dumpsite is the major municipal solid wastes (MSW) dumpsite in Owerri Municipal, the capital of Imo State, South-Eastern Nigeria. This dumpsite which occupies about five (5) hectares of arable land has become a source of concern to both local and state authorities. The objective of this study was to determine the effect of municipal solid wastes on selected Njoku saw mill dumpsite soil enzymes activities, inorganic anions and exchangeable cations associated with soil fertility.

\section{Materials and Methods Study Area}

Njoku Saw mill dump site in Owerri Muncipal of Imo State, Nigeria, is located along Owerri - Aba Road. This dumpsite occupies about five hectares of arable land and wastes dumped there include domestic wastes, broken glasses, salon refuses, discarded furniture materials, hotel leftovers, old clothing materials, old batteries and environmental sanitation wastes from Owerri. The main occupation of inhabitants around this dump site is farming. Njoku Sawmill is one of the Imo State Environmental Protection Agency (ISEP) waste disposal sites in owerri metropolis,Nigeria. It is located between latitude $5^{\circ} 27^{\prime} \mathrm{N}$ and longitude $7^{\circ} 14^{\prime} \mathrm{E}$ on an elevation of about $65 \mathrm{~m}$ above sea level and occupy an area of about $5.5 \mathrm{~km}^{2}$. Below is the map showing the study area.

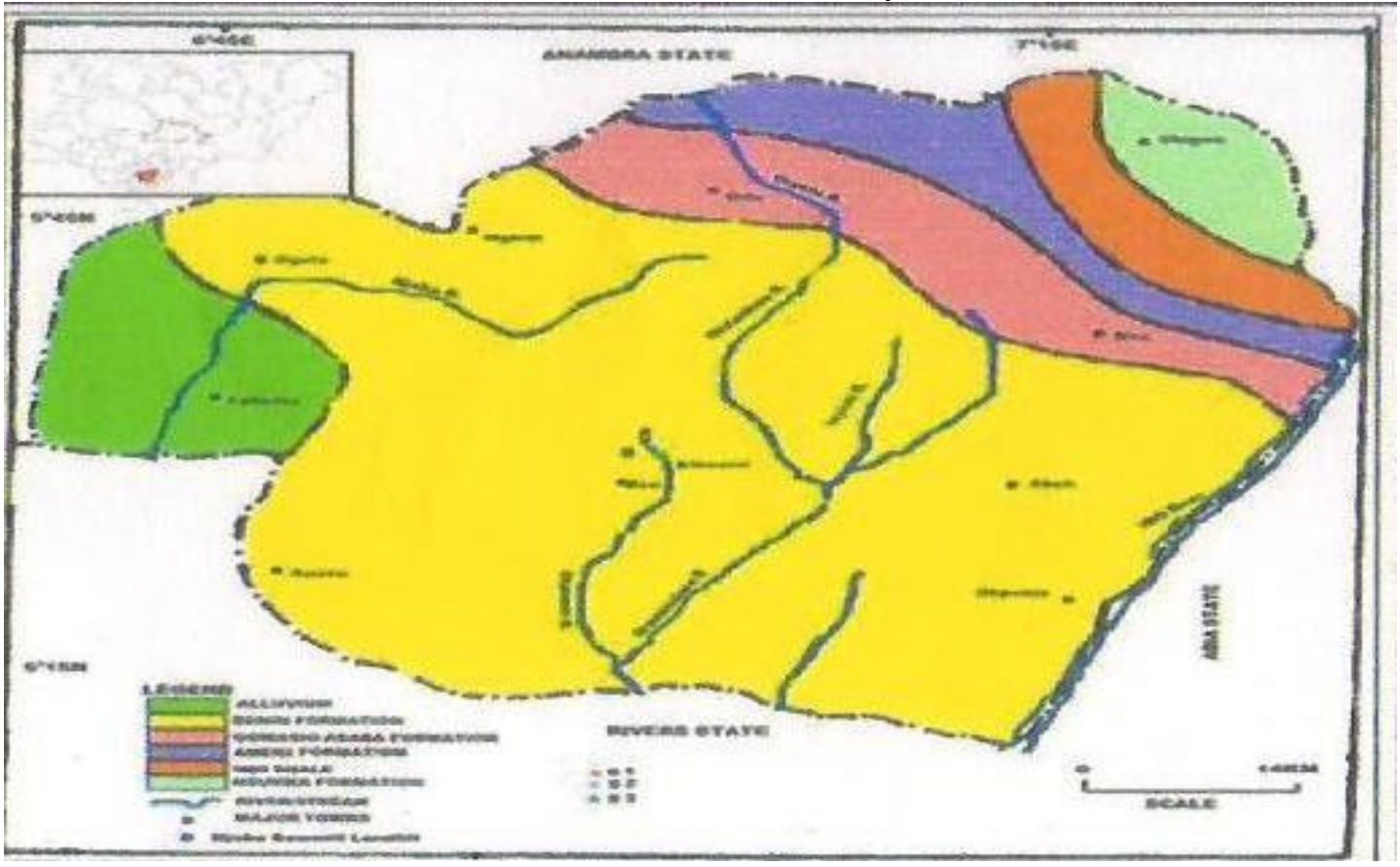

Figure 1 Geological map of study area 


\section{Collection of Soil Samples}

The polluted sites were divided into three and classified as either heavily, moderately and lightly polluted. Land within 150 meters of the dump site represents the heavily polluted area, land within 150 - 200 meters represents the moderately polluted and 200 - 250meters, lightly polluted. An unpolluted area around the dumpsite served as the control. The soil samples were collected separately using metal augers and stored in air tight cellophane bags. The samples were transported down to Abia State University, Uturu, immediately for analysis in a refrigerated cooler to arrest microbial growth. Unanalyzed samples were stored in a refrigerator $\left(3-6^{\circ} \mathrm{c}\right)$ to avoid decay.

\section{Physicochemical Analysis}

Soil $\mathrm{pH}$ was determined using Bates, (1954) method while soil temperature was determined at the site of sample collection using mercury-in-glass thermometer. Soil organic carbon /organic matter were determined as described by Agbenin, (1995). Soil nitrate was measured according to the method of Allen et al., (1974) while soil sulphate and phosphate were determined as described by Dewis and Freitas, (1970). Soil moisture was measured using the procedure described by APHA, (1998).

\section{Soil Enzyme Analysis}

The soil lipase activity was determined according to the method of Macedo et al., (1997) while soil acid and alkaline phsophatases were obtained using the method of Tabatabai and Bremmer, (1969). Similarly, soil hydrogen peroxidase was measured by titrimetric method as described by Alef and Nannipieri, (1995). However, soil dehydrogenase activity was estimated as described by Casida et al., (1964). The measurement of soil urease activity was done using the method of Nannipieri et al., (1980) as modified by Kandeler and Gerber (1988).

\section{Soil Exchangeable Cations and Trace Metals}

The method of atomic absorption spectrophotometry was used for the determination of exchangeable cations and trace metals present in the soil samples. The spectrophotometer (Perkin-Elmer Model 403) after standardization with standard solution of the element being analyzed was acidified and distilled water added to zero the instrument. Then sample extracts were aspirated and concentrations read off the instrument.

\section{Results}

The results of the physicochemical parameters and concentrations of anions in the polluted and unpolluted soils of Njoku waste dumpsite Owerri Municipal are presented in Table 1. Variations in the physicochemical parameters and concentrations of anions between the polluted and unpolluted soils were observed in all three points within the dumpsite studied. The data indicated increased soil $\mathrm{pH}$ values with increased pollution. However only the heavily polluted areas showed significantly $(\mathrm{p} \leq 0.05)$ higher soil $\mathrm{pH}$ than the unpolluted area. Similarly polluted soil temperatures and percentage moistures were significantly $(p \leq 0.05)$ higher than unpolluted soils with the exception of the lightly polluted areas. Organic carbon and organic matters content of the test soils increased significantly with increased pollution (refuse dumping). The soil nitrate concentration was significantly higher $(\mathrm{p} \leq 0.05)$ within the heavily polluted areas of the dumpsite than other areas including the unpolluted points. However, polluted soil $\mathrm{SO}^{2-}$ and $\mathrm{PO}^{3-}{ }_{4}$ concentrations significantly $(\mathrm{p} \leq 0.05)$ increased with increased soil pollution when compared to unpolluted (control) soil samples. In table II, the exchangeable cations and trace metals concentrations of the studied waste dumpsite are presented. There were significantly $(\mathrm{P}<0.05)$ increased concentrations of the exchangeable cations and trace metals with increased pollution (waste dumping) compared to control sites. The differences in the polluted soils selected enzymes activities in the study areas are presented in table III. There were significantly higher $(\mathrm{p} \leq 0.05)$ soil dehydrogenase, lipase, acid phsophatase, peroxidase and urease activities with increased 
pollution compared to control soil samples. However no significant changes $(p \geq 0.05)$ in the test soils alkaline phosphatase activity were observed in relation to control soil samples.

\section{Discussion}

Result in Table 1 indicate that the dumping of wastes on the studied dumpsite increased the soil $\mathrm{pH}$ progressively with increased assault. Reports on changes in the $\mathrm{pH}$ of various wastes dumpsite soils have been presented by many workers (Ogboghedo et al., 2006; Olorunfemi et al., 2007 and Nwaugo et al., 2007b). Changes in soil $\mathrm{pH}$ have been noted to affect plant growth at dumpsites (Okwute and Isu, 2007a). These observed increases in soil $\mathrm{pH}$ and temperatures of this dumpsite in relations to control may be attributable to enhanced microbial activities (Akubugwo et al., 2007). Similarly the dumping of wastes encouraged soil moisture retention and increased soil organic matter content. The breakdown of the high organic matter content of the dumpsite soil by microorganisms being exothermic led to increased soil temperatures observed while the metabolism of the protein content of household wastes released ammonia (Shanhinirokhsar et al., 2008). The ammonia dissolved in the available moisture to cause the reported increase in $\mathrm{pH}$ value. Similar observations had been reported by Nwaugo et al., (2008a) and Chinyere (2001) on effluent dumpsite soils. The above observations may have influenced soil nitration and urease enzyme activities which increased significantly at the heavily polluted areas of this dumpsite compared to control (non polluted) areas. The anions, nitrate $\left(\mathrm{NO}_{3}{ }^{-}\right)$, sulphate $\left(\mathrm{SO}_{4}{ }^{2-}\right)$ and phosphate $\left(\mathrm{PO}_{4}{ }^{2-}\right)$ are important for plant growth. Soil nitrate is an important source of nitrogen to plants which is used for synthesis of nitrogen containing compounds.

Similarly sulphate ions in soils provide plants and microorganisms sulphur essential for all living organisms. The observed increase in soil sulphate ion of the polluted dumpsite soil studied may have arisen from organic sulphur containing remains of plant and animal wastes. However inorganic sulphur contribution to this dumpsite soil sulphate ion may likely be from industrial wastes dumped within the dumpsite environment. All these sulphur will be transformed to sulphate and assimilated through the sulphate assimilation pathway by plants. Acidification of soil due to high soil sulphate ion results in aluminium dissociation which inhibits root elongation and nutrient uptake (Ma et al., 2001). In soil, phosphorus (P) exists in mostly organic and inorganic forms both of which are important sources of phosphorus for plant and microbial uptake ( $\mathrm{Li}$ et al., 2002). The organic forms exists as phosphates mostly in humus and other organic materials while inorganic $\mathrm{P}$ are in various combinations of $\mathrm{Al}, \mathrm{Fe}, \mathrm{Mg}, \mathrm{CA}$ and other elements (Lyons et al., 1998). These are probable sources of the high phosphate concentration observed in the heavily polluted areas of this dumpsite. The trace metals $(\mathrm{Cu}$, $\mathrm{Mn}, \mathrm{Fe}$ and $\mathrm{Zn}$ ) were equally significantly $(p \leq 0.05)$ higher in the heavily polluted areas of the dumpsite compared to lightly polluted and control points. It is believed that these increases arose from household utensils and probably electronic wastes dumped within this site. The high concentration of iron observed may tie-up phosphorus, thus making phosphate ion unavailable to plants (Eivazi and Tabatabai, 1977). Similarly, high soil $\mathrm{pH}$ than $\mathrm{pH} 7.3$ leads to phosphorus being tied-up as calcium phosphates and made unavailable to plants. This will in effect discourage plant growth as observed in this dumpsite.

Sodium, potassium, magnesium, calcium and hydrogen are the major soil cations (Davies et al., 2003). They have charges of varying strength acting as exchange sites which creates antagonistic relationship among the cations being in constant competition for available space on soil particles (Brady, 1984). As a result an excess of one cation leads to a deficiency of another. High soil sodium ion (as obtained in this study) leads to reduced soil permeability resulting to drainage and 
compaction problems. Plants may therefore not be able to survive the ensuing permeability problems (Clansy, 1981). The principal causes of soil sodium accumulation has been cited (Tam, 1998) as excess soil bicarbonate and carbonate ions which freely reacts within soluble soil calcium and magnesium.

The dumpsite soil enzymes activities increased with increased waste impaction. Soil enzymes play key biochemical functions in the overall process of organic matter decomposition in the soil system (Sinsabaugh et al., 1991). The enzyme levels in the soil system vary in amounts of organic matter content composition and activity of its living organisms and intensity of the biological processes (Stevenson, 1986). These enzymes arise from microorganisms, plants and animals within the soil ecosystem.

In this study, the dehydrogenase activity in the soil increased with increased waste assault. The dehydrogenase enzyme activity is commonly used as an indicator of biological activity in soils and index of soil fertility (Burns, 1978). The observed significantly high $(p \leq 0.05)$ soil dehydrogenase activity in the heavily polluted portions of the dumpsite shows increased microbial activity i.e. waste decomposition. The process will eventually untie various nutrients for plants and microorganism use (McCarthy et al., 1994). Soil lipases are produced from a variety of bacteria, fungi, plants and animals (Brune and Gotz, 1992). Costra-Ochoa et al., (2005) reported that contamination of soil with effluent containing various forms of oil affects the activity of the soil lipase enzyme. This explains in part the high soil lipase enzyme activity observed in this study. Similarly Colin et al., (2010) cited that most soil lipases emanate from plant and animal sources e.g. worms, dead plant products and decaying animal remains.

The increased soil hydrogen peroxidase activity obtained is attributed to nutrients availability and increased oxidation-reduction reactions taking place within the dumpsite soils. Although there was high soil phosphate concentration $(\mathrm{p} \leq 0.05)$, the soil acid phosphatase level was equally high $(\mathrm{p} \leq 0.05)$. This is an indicator that the phosphate ions in the soils were tied-up and made unavailable to plants and microorganisms. In soil ecosystems, phosphatases play critical roles in P-cycle (Speir and Ross, 1978) as evidences show that they are correlated to P-stress and plant growth (Dick et al., 2000). Transcription activity of acid phosphatases tends to increase in plants and microorganism with high P-stress (Li et al., 2002). When there is a signal indicating phosphorus deficiency in the soil, acid phosphatase secretion from plant roots and microorganisms is increased to enhance the solubilization and remobilization of the phosphate thus influencing the ability of the plant to cope with P-stressed conditions (Kai et al., 2002, Ndakidemi, 2006, Karthikayan et al., 2002). This is a probable explanation of the results obtained in this study for dumpsite acid phosphatase. Their inducibility and exudation by plant roots and microbes are determined by orthophosphate need of these organisms which in turn is affected by soil pH (Skujins, 1976). However the alkaline phosphatase activity was not influenced by waste dumping. The dumpsite soil urease enzyme was found to be significantly high $(\mathrm{p} \leq 0.05)$ in the highly polluted areas of the dumpsite. This enzyme originates mainly from plants (Polacce, 1977) and microorganisms (Mobley and Hausinger, 1989) found as both intra and extracellular enzymes. Its high level $(\mathrm{p} \geq 0.05)$ in the heavily polluted portions of this dumpsite is associated with urea containing household wastes dumped there. Urease activity in the soil is influenced by organic matter content of soil, soil depth, level of soil contamination, $\mathrm{pH}$ and temperature (Yang et al., 2006). The $\mathrm{NH}_{4}^{+}$produced as a result of urease activity in the heavily polluted areas may have led to increase of the dumpsite $\mathrm{pH}$ in these areas to alkaline. 
Table 1 Physicochemical Parameters and Anions of Polluted Soils from Njoku Waste Dumpsite, Owerri Municipal

\begin{tabular}{|c|c|c|c|c|c|c|c|c|c|c|}
\hline Soil & \multicolumn{3}{|c|}{ Heavily polluted } & \multicolumn{3}{|c|}{ Moderately polluted } & \multicolumn{3}{|c|}{ Lightly polluted } & Control \\
\hline Temperature $\left({ }^{\circ} \mathrm{c}\right)$ & $33.6 \pm 0.02^{\mathrm{a}}$ & $33.9 \pm 0.01^{\mathrm{a}}$ & $33.4 \pm 0.13^{\mathrm{a}}$ & $31.2 \pm 0.21^{\mathrm{a}}$ & $32.2 \pm 0.18^{\mathrm{a}}$ & $31.4 \pm 0.15^{\mathrm{a}}$ & $29.6 \pm 0.24^{\mathrm{b}}$ & $30.3 \pm 0.20^{\mathrm{ab}}$ & $28.8 \pm 0.01^{\mathrm{b}}$ & $27.3 \pm 0.15^{\mathrm{b}}$ \\
\hline Moisture (\%) & $26.74 \pm 0.10^{\mathrm{a}}$ & $25.60 \pm 0.62^{\mathrm{a}}$ & $26.11 \pm 0.15^{\mathrm{a}}$ & $22.19 \pm 0.95^{\mathrm{b}}$ & $23.71 \pm 0.27^{\mathrm{b}}$ & $24.14 \pm 0.33^{\mathrm{a}}$ & $19.60 \pm 0.03^{\mathrm{c}}$ & $19.26 \pm 0.28^{\mathrm{c}}$ & $20.99 \pm 0.15^{b}$ & $19.64 \pm 0.40^{c}$ \\
\hline $\begin{array}{l}\text { Organic } \quad \text { Carbon } \\
(\%)\end{array}$ & $3.91 \pm 0.19^{\mathrm{a}}$ & $3.84 \pm 0.17^{\mathrm{a}}$ & $3.79 \pm 0.14^{\mathrm{a}}$ & $3.08 \pm 0.32^{\mathrm{a}}$ & $3.12 \pm 0.17^{\mathrm{a}}$ & $3.05 \pm 0.15^{\mathrm{a}}$ & $2.09 \pm 0.27^{\mathrm{b}}$ & $2.43 \pm 0.18^{\mathrm{ab}}$ & $2.01 \pm 0.92^{\mathrm{b}}$ & $0.96 \pm 0.17^{\mathrm{c}}$ \\
\hline Organic matter & $6.47 \pm 0.12^{\mathrm{a}}$ & $5.13 \pm 0.14^{\mathrm{a}}$ & $5.91 \pm 0.67^{\mathrm{a}}$ & $5.10 \pm 0.11^{\mathrm{a}}$ & $5.19 \pm 0.33^{\mathrm{a}}$ & $4.98 \pm 0.41^{\mathrm{a}}$ & $4.33 \pm 0.61^{\mathrm{a}}$ & $4.01 \pm 1.01^{\mathrm{a}}$ & $4.13 \pm 0.51^{\mathrm{a}}$ & $1.29 \pm 0.18^{\mathrm{b}}$ \\
\hline Phosphate $\left(\mathrm{mgKg}^{-1}\right)$ & $9.61 \pm 0.03^{\mathrm{a}}$ & $8.69 \pm 0.45^{\mathrm{a}}$ & $8.88 \pm 0.19^{\mathrm{a}}$ & $9.03 \pm 0.45^{\mathrm{a}}$ & $9.02 \pm 0.62^{\mathrm{a}}$ & $7.98 \pm 0.49^{\mathrm{ad}}$ & $6.66 \pm 0.13^{\mathrm{db}}$ & $5.81 \pm 0.81^{\mathrm{b}}$ & $5.13 \pm 0.81^{\mathrm{b}}$ & $4.21 \pm 0.15^{\mathrm{b}}$ \\
\hline
\end{tabular}

Results are mean of triplicate determinations \pm standard deviation (SD)

$\mathrm{P}_{1}, \mathrm{P}_{2} \mathrm{P}_{3}$ are different points of soil samples collection within the polluted areas.

Points with same alphabets are not significantly different $(\mathrm{P}>0.05)$

Depth of sample collection at each point $\mathrm{P}=0.30 \mathrm{~cm}$ 
Table Exchangeable Cations and Trace Metal Concentrations of Polluted Soils from Njoku Waste Dumpsite, Owerri Municipal

\begin{tabular}{|c|c|c|c|c|c|c|c|c|c|c|}
\hline \multirow[t]{2}{*}{ Soil } & \multicolumn{3}{|c|}{ Heavily polluted } & \multicolumn{3}{|c|}{ Moderately polluted } & \multicolumn{3}{|c|}{ Lightly polluted } & \multirow[t]{2}{*}{ Control } \\
\hline & $\mathrm{P}_{1}$ & $\mathrm{P}_{2}$ & $\mathrm{P}_{3}$ & $\mathrm{P}_{1}$ & $\mathrm{P}_{2}$ & $\mathrm{P}_{3}$ & $\mathrm{P}_{1}$ & $\mathrm{P}_{2}$ & $\mathrm{P}_{3}$ & \\
\hline$+\mathrm{Ca}\left(\mathrm{mg} 100 \mathrm{~g}^{-1}\right)$ & $13.01 \pm 0.18^{\mathrm{a}}$ & $13.00 \pm 0.34^{\mathrm{a}}$ & $13.00 \pm 0.41^{\mathrm{a}}$ & $13.01 \pm 0.11^{\mathrm{a}}$ & $12.81 \pm 0.32^{\mathrm{a}}$ & $11.04 \pm 0.61^{\mathrm{b}}$ & $8.21 \pm 0.38^{\mathrm{c}}$ & $8.20 \pm 0.19^{c}$ & $7.15 \pm 0.15^{\mathrm{d}}$ & $1.88 \pm 0.06^{\mathrm{e}}$ \\
\hline$+\operatorname{Mg}\left(\mathrm{mg} 100 \mathrm{~g}^{-1}\right)$ & $10.41 \pm 0.21^{\mathrm{a}}$ & $10.50 \pm 0.27^{\mathrm{a}}$ & $9.98 \pm 0.14^{\mathrm{a}}$ & $9.01 \pm 0.18^{\mathrm{b}}$ & $9.33 \pm 0.14^{\mathrm{b}}$ & $8.61 \pm 0.11^{\mathrm{c}}$ & $8.88 \pm 0.53^{\mathrm{b}}$ & $6.51 \pm 0.17^{\mathrm{d}}$ & $8.73 \pm 0.18^{b}$ & $2.95 \pm 0.06^{\mathrm{e}}$ \\
\hline$+\mathrm{Na}\left(\mathrm{Mg} 100 \mathrm{~g}^{-1}\right)$ & $\begin{array}{l}130.00 \pm 0.2 \\
0^{\mathrm{a}}\end{array}$ & $\begin{array}{l}127.01 \pm 0.1 \\
8^{\mathrm{a}}\end{array}$ & $\begin{array}{l}137.15 \pm 0.6 \\
1^{\mathrm{a}}\end{array}$ & $98.67 \pm 0.31^{b}$ & $\begin{array}{l}101.00 \pm 0.1 \\
5^{\mathrm{b}}\end{array}$ & $71.16 \pm 0.21^{\mathrm{c}}$ & $49.33 \pm 0.33^{\mathrm{d}}$ & $52.61 \pm 0.70^{d}$ & $38.00 \pm 0.15^{\mathrm{e}}$ & $30.00 \pm 0.19^{f}$ \\
\hline$+\mathrm{k}\left(\mathrm{Mg} 100 \mathrm{~g}^{-1}\right)$ & $23.00 \pm 0.15^{\mathrm{a}}$ & $21.15 \pm 0.17^{\mathrm{b}}$ & $18.62 \pm 0.40^{\mathrm{c}}$ & $10.15 \pm 0.13^{\mathrm{d}}$ & $16.36 \pm 0.01^{\mathrm{e}}$ & $13.00 \pm 0.03^{\mathrm{f}}$ & $14.06 \pm 0.18^{\mathrm{f}}$ & $11.60 \pm 0.13^{\mathrm{d}}$ & $13.30 \pm 0.10^{\mathrm{f}}$ & $9.30 \pm 0.19^{\mathrm{h}}$ \\
\hline$++\mathrm{Cu}\left(\mu \mathrm{g} \mathrm{g}^{-1}\right)$ & $\begin{array}{l}506.00 \pm 0.1 \\
8^{\mathrm{a}}\end{array}$ & $\begin{array}{l}611.60 \pm 0.3 \\
2^{\mathrm{b}}\end{array}$ & $\begin{array}{l}525.10 \pm 0.1 \\
6^{\mathrm{a}}\end{array}$ & $360.60 \pm 0.19^{c}$ & $\begin{array}{l}271.00 \pm 0.3 \\
2^{\mathrm{d}}\end{array}$ & $\begin{array}{l}358.60 \pm 0.2 \\
3^{c}\end{array}$ & $23.00 \pm 0.13^{\mathrm{e}}$ & $18.96 \pm 0.23^{\mathrm{e}}$ & $8.10 \pm 0.28^{\mathrm{f}}$ & $0.61 \pm 0.03^{h}$ \\
\hline$++\mathrm{Mn}\left(\mathrm{mg} 100 \mathrm{~g}^{-1}\right)$ & $3.23 \pm 0.14^{\mathrm{a}}$ & $2.80 \pm 0.23^{\mathrm{a}}$ & $1.91 \pm 0.31^{\mathrm{b}}$ & $2.41 \pm 0.03^{\mathrm{a}}$ & $1.89 \pm 0.10^{\mathrm{b}}$ & $0.93 \pm 0.23^{\mathrm{c}}$ & $1.01 \pm 0.15^{\mathrm{c}}$ & $0.38 \pm 0.10^{c}$ & $0.69 \pm 0.08^{\mathrm{c}}$ & $0.15 \pm 0.06^{\mathrm{c}}$ \\
\hline$++\mathrm{Fe}\left(\mathrm{mg} 100 \mathrm{~g}^{-1}\right)$ & $\begin{array}{l}304.03 \pm 0.6 \\
9^{\mathrm{a}}\end{array}$ & $\begin{array}{l}362.06 \pm 0.3 \\
1^{\mathrm{b}}\end{array}$ & $\begin{array}{l}341.00 \pm 0.1 \\
8^{\mathrm{b}}\end{array}$ & $348.90 \pm 0.49^{\mathrm{b}}$ & $\begin{array}{l}267.00 \pm 0.1 \\
8^{\mathrm{c}}\end{array}$ & $\begin{array}{l}209.32 \pm 0.2 \\
2^{\mathrm{d}}\end{array}$ & $\begin{array}{l}177.20 \pm 0.6 \\
3^{\mathrm{e}}\end{array}$ & $\begin{array}{l}201.30 \pm 0.9 \\
5^{\mathrm{d}}\end{array}$ & $\begin{array}{l}169.00 \pm 0.1 \\
3^{\mathrm{e}}\end{array}$ & $23.40 \pm 0.08^{\mathrm{f}}$ \\
\hline$++Z n\left(\mu g^{-1}\right)$ & $\begin{array}{l}145.20 \pm 0.1 \\
9^{\mathrm{a}}\end{array}$ & $\begin{array}{l}138.15 \pm 0.3 \\
7^{\mathrm{a}}\end{array}$ & $\begin{array}{l}162.91 \pm 0.5 \\
0^{\mathrm{b}}\end{array}$ & $128.97 \pm 0.81^{\mathrm{c}}$ & $89.32 \pm 0.91^{\mathrm{d}}$ & $\begin{array}{l}110.28 \pm 0.3 \\
1^{\mathrm{c}}\end{array}$ & $37.98 \pm 0.11^{\mathrm{e}}$ & $52.33 \pm 0.20^{\mathrm{f}}$ & $\begin{array}{l}103.61 \pm 0.2 \\
9^{c}\end{array}$ & $0.69 \pm 0.09^{\mathrm{h}}$ \\
\hline $\begin{array}{l}+=\text { Exch } \\
++=\text { Trace } \\
\text { Results are } \\
\mathrm{P}_{1}, \mathrm{P}_{2} \mathrm{P}_{3} \text { ar } \\
\text { Points witl } \\
\text { Depth of } \mathrm{s}\end{array}$ & $\begin{array}{l}\text { ngeable Catic } \\
\text { metals } \\
\text { mean of tripl } \\
\text { different poi } \\
\text { same alphab } \\
\text { mple collecti }\end{array}$ & $\begin{array}{l}\text { cate determir } \\
\text { its of soil san } \\
\text { ts are not sig } \\
\text { n at each poi }\end{array}$ & $\begin{array}{l}\text { ations } \pm \text { stan } \\
\text { ples collectio } \\
\text { ificantly diff } \\
\text { t } \mathrm{P}=0.30 \mathrm{~cm}\end{array}$ & $\begin{array}{l}\text { ard deviation } \\
n \text { within the po } \\
\text { erent }(P>0.05)\end{array}$ & $\begin{array}{l}\text { D) } \\
\text { luted areas. }\end{array}$ & & & & & \\
\hline
\end{tabular}


Table 3 Selected Soil Enzymes Activities of Polluted Soils from Njoku Waste Dumpsite, Owerri Municipal

\begin{tabular}{|c|c|c|c|c|c|c|c|c|c|c|}
\hline \multirow[t]{2}{*}{ Soil } & \multicolumn{3}{|c|}{ Heavily polluted } & \multicolumn{3}{|c|}{ Moderately polluted } & \multicolumn{3}{|c|}{ Lightly polluted } & \multirow[t]{2}{*}{ Control } \\
\hline & $\mathrm{P}_{1}$ & $\mathrm{P}_{2}$ & $\mathrm{P}_{3}$ & $\mathrm{P}_{1}$ & $\mathrm{P}_{2}$ & $\mathrm{P}_{3}$ & $\mathrm{P}_{1}$ & $\mathrm{P}_{2}$ & $\mathrm{P}_{3}$ & \\
\hline Dehydrogenase $\left(\mathrm{mg} \mathrm{g}^{-1} 6 \mathrm{~h}^{-1}\right)$ & $8.22 \pm 0.11^{\mathrm{c}}$ & $8.89 \pm 0.61^{\mathrm{c}}$ & $7.43 \pm 0.92^{\mathrm{ac}}$ & $6.95 \pm 0.11^{\mathrm{a}}$ & $7.23 \pm 0.15^{\mathrm{a}}$ & $7.13 \pm 0.20^{\mathrm{a}}$ & $5.33 \pm 0.17^{\mathrm{d}}$ & $5.09 \pm 0.61$ & $\begin{array}{l}4.71 \pm 0.09 \\
\mathrm{~b}\end{array}$ & $3.48 \pm 0.41^{\mathrm{e}}$ \\
\hline Lipase $\left(\mathrm{mg} \mathrm{g}^{-1} \mathrm{~h}^{-1}\right)$ & $11.62 \pm 0.27^{\mathrm{a}}$ & $10.91 \pm 0.31^{\mathrm{a}}$ & $10.89 \pm 0.16^{\mathrm{a}}$ & $8.71 \pm 0.10^{b}$ & $8.61 \pm 0.33^{b}$ & $8.52 \pm 0.10^{b}$ & $5.81 \pm 1.63^{\mathrm{c}}$ & $\begin{array}{l}8.45 \pm 0.89 \\
b\end{array}$ & $\begin{array}{l}8.71 \pm 0.16 \\
b\end{array}$ & $2.24 \pm 0.81^{\mathrm{d}}$ \\
\hline $\begin{array}{l}\text { Acid Phosphatase } \\
\left(\mathrm{mgPNPg}^{-1} \text { dry soil } \mathrm{h}^{-1}\right)\end{array}$ & $38.21 \pm 1.03^{\mathrm{a}}$ & $38.68 \pm 0.91^{\mathrm{a}}$ & $36.88 \pm 1.00^{\mathrm{a}}$ & $27.56 \pm 0.69^{\mathrm{b}}$ & $27.86 \pm 1.96^{\mathrm{b}}$ & $27.40 \pm 1.60^{\mathrm{b}}$ & $25.83 \pm 0.96^{\mathrm{b}}$ & $\begin{array}{l}27.15 \pm 1.1 \\
0^{\mathrm{b}}\end{array}$ & $\begin{array}{l}27.48 \pm 0.6 \\
8^{\mathrm{b}}\end{array}$ & $26.84 \pm 0.29^{b}$ \\
\hline $\begin{array}{l}\text { Alkaline Phosphatase (mg } \\
\text { PNPg }^{-1} \text { dry soil }^{-1} \text { ) }\end{array}$ & $12.43 \pm 0.73^{\mathrm{a}}$ & $12.38 \pm 0.33^{\mathrm{a}}$ & $12.32 \pm 0.55^{\mathrm{a}}$ & $12.66 \pm 0.21^{\mathrm{a}}$ & $12.14 \pm 0.26^{\mathrm{a}}$ & $12.56 \pm 0.51^{\mathrm{a}}$ & $12.38 \pm 0.68^{\mathrm{a}}$ & $\begin{array}{l}10.57 \pm 0.6 \\
3^{b}\end{array}$ & $\begin{array}{l}13.11 \pm 0.0 \\
3^{\mathrm{a}}\end{array}$ & $12.93 \pm 0.33^{\mathrm{a}}$ \\
\hline Hydrogen peroxidase & $5.88 \pm 0.94^{\mathrm{a}}$ & $6.45 \pm 0.63^{\mathrm{b}}$ & $6.67 \pm 0.11^{\mathrm{b}}$ & $6.89 \pm 0.96^{\mathrm{b}}$ & $5.56 \pm 0.58^{\mathrm{a}}$ & $4.71 \pm 0.82^{\mathrm{c}}$ & $5.12 \pm 0.71^{\mathrm{a}}$ & $\begin{array}{l}4.89 \pm 0.75 \\
\mathrm{ac}\end{array}$ & $\begin{array}{l}3.97 \pm 0.15 \\
c\end{array}$ & $4.76 \pm 0.91^{\mathrm{c}}$ \\
\hline $\begin{array}{l}\text { Urease (mg NH } \mathrm{NH}_{3}-\mathrm{Ng}^{-1} \text { dry } \\
\left.\text { soil } 5 \mathrm{~h}^{-1}\right)\end{array}$ & $4.61 \pm 0.06^{\mathrm{a}}$ & $4.16 \pm 0.01^{\mathrm{a}}$ & $4.48 \pm 0.07^{\mathrm{a}}$ & $3.91 \pm 0.03^{\mathrm{a}}$ & $3.82 \pm 0.05^{\mathrm{a}}$ & $3.51 \pm 0.04^{\mathrm{ab}}$ & $3.09 \pm 0.10^{\mathrm{b}}$ & $2.93 \pm 0.31$ & $\underset{b}{2.96 \pm 0.14}$ & $1.99 \pm 0.08^{\mathrm{c}}$ \\
\hline
\end{tabular}

Results are mean of triplicate determinations \pm standard deviation (SD)

$\mathrm{P}_{1}, \mathrm{P}_{2} \mathrm{P}_{3}$ are different points of soil samples collection within the polluted areas.

Points with same alphabets are not significantly different $(\mathrm{P}>0.05)$

Depth of sample collection at each point $\mathrm{P}=0.30 \mathrm{~cm}$. 


\section{Conclusion}

This study has shown that dumping solid wastes at Njoku Saw mill dumpsite increased most of the parameters used as indices of soil fertility. However increased soil temperature, $\mathrm{pH}$ and moisture content with increased waste dumping discouraged plants growth. Similarly most of the nutrients were probably made unavailable to plants and microorganisms. This therefore calls for proper management of this dumpsite through solid waste treatment procedures before use for agricultural purposes.

\section{References}

Agbenin, J.O. (1995), Laboratory Manual for soil and plants analysis. Faculty of Agriculture and Institute of Agricultural Research. A.B.U. Zaria. 7, 7-1.

Akubugwo, E.I., Ofoegbu, C.J. and Ukwuoma, C.U. (2007), Physicochemical Studies on Ubru Salt Lake Ebonyi State Nigeria. Pakistan Journal of Biological Sciences 7, 3170 - 3174.

Alef, K. and Nannipieri, P. (1995). Methods in Applied Soil Microbiology and Biochemistry. 3rd edition. Academic Press London. pp. 345 - 353.

Allen, S.E., Grinshaw, H., Parkinson, J.A. and Quarmby, C. (1974), Chemical analysis of econological materials. Blackwell Scientific Publication, London. Pp. 41.

APHA (1998), Standard methods for the examination of water and waste water. 18th edn. Washington (American Public Health Association). $89-141$.

Bates, R.G. (1954), Electronic pH determination. John Wiley and Sons Inc. New York.

Brady, W.C. (1984), The nature and properties of soils. Macmillian Publishers London. England. 6183.

Brune, A.K. and Gotz, F. (1992), Degradation of lipids by Bacterial Lipases. In: Microbial Degradation of Natural Products; Winkelman, G. (Ed) VCH; Weinhein, pp. 243- 266.

Cassida, L.E., Wein, J.D. and Santoro, D. (1964), Soil dehydrogenase activity. Soil Science, 98,371 374.

Chinyere, G.C. (2001), Effect of effluents from cassava processing plants on soil cyanide levels; A case study of Okigwe in Imo State and Ovim
Ahaba Imenyi in Abia State, Nigeria. Journal of Health and Visual Sciences, 3(3), 88-93.

Clansy, K.P. (1981), Sodium affected soils. Western Fertilitizer Bulletin, 48, 58-62.

Colin, V.L., Baigori, M.D. and Pera, L.M. (2010), Effect of Environmental condition on extracellular lipases production and Fungi morphology from Aspergillus Diger MYA 135. Journal of Basic Micobiology, 50, 52 - 58.

Costra - Ochoa, L.D., Rodriquez, C., Valeno-AlLaro, G. and Ros, R.O. (2005), Screening purification and characterization of the thermoalkalophilic lipase produced by Bacilus thermoleovoraus CCR II. Enzyme Microbiology and Technology, 37, 648-654.

Davies, J.G., Waskom, R.M. and Cardo, G.E. (2003), Managing sodic soil. Soil and Crop Sciences 98, 371 - 374.

Dewis, J. and Fretias, F. (1970), Physicla and Chemical Methods of soil and water analysis. Soil Bulletin 10 FAD Rome. Pp 1-275.

Dick, R.P., Sandor, J.A. and Eash, D.S. (1994), Soil enzyme activities alter 1500 years of terrace agriculture in the Colca valley, Peru Agriculture, Ecology and Environmental, 50, 123 - 131.

Dick, R.P. (1997), Soil enzyme activities as integrative indicators of soil health. In: Pankhurst CE, Doube B.M., Gupta rVSR (Eds). Biological indicators of soil Health, CAB International, Wellingford. 121- 156.

Dick, W.A., Change, L. and Wang, P. (2000), Soil Acid and Alkaline Phosphatase Activity as $\mathrm{pH}$ adjustment indicators. Soil Biology and Biochemistry, 32, 1915 - 1919.

Eivazi, F. and Tabatabai, M.A. (1977), Phosphatases in Soils: Soil Biology. Biochemistry, 9(3), 167 - 172. Kai, M., Takazumi, K. Adachi, H., Wasaki, J., Shinano, T. and Osaki, M. (2002), Cloning and Characterization of four phosphate transporter DNAs in tobacco. Plant Science. 163, 837 - 846.

Kandeler, E. and Gerber, H. (1998), Short term assay of soil urease activity using colorimetric determinations of ammonium ion. Biology and Fertility of Soils, 6, $68-72$.

Karthikayan, A.S., Varadarajan, D.K., Mukatira, U.T., D'Urzo, M.P., Damaz, B. and Raghothama, K.G. (2002), Regulated expression of Arabidopsis phosphate transporters, Plant Physiology, 30, 221233. 
Li, D., Zhu, H., Liu, K., Liu, X., Leggewie, G., Udvardi, M. and Wang, D. (2002), Purple acid phosphatase of Arabidopsis thalian, Journal of Biological Chemistry, 277, 27772 - 27781.

Ma, Jian Feng; Fyan, Peter, R. and Dethaize, Emmanuel (2001), Alumnium tolerance in plants and the complexing role of organic acids. Trends in Plant Science, 6(6), 273 - 298.

Macedo, G.A., Park, Y.K. and Pastor, G.M. (1997), Partial purification of lipase from a newly strain of Geotrichum spp. Review of Microbiology 28, 90-95.

Makoi, J.H.J.R. and Ndakidemi, P.A. (2008), Selected soil enzymes. Examples of their potential roles in the ecosystem. African Journal of Biotechnology, 7(3), 181-191.

McCarthy, G.W., Siddaramappa, R., Reight, R.J., Coddling, E.E. and Goa, G. (1994), Evaluation of coal combustion by products as soil liming materials: their influence on soil properties and enzyme activities, Biology and Fertility of Soils, 17, $167-172$.

Mobley, H.L.T. and Hausinger, R.P. (1989), Microbial Urease: significance, regulation and molecular characterization. Microbiology Review, 53, $85-108$.

Nannipieri, P.B., Crescenti, S. and Cerevelli, E. (1980), Extraction of phosphatase, urease, protease, organic carbon and nitrogen from soil. Soil Science Society of America Journal, 44, 1011-1016.

Ndakidemi, P.A. (2006), Manipulating legume/cereal mixtures to optimize the above and below ground interaction cropping systems. African Journal of Biotechnology, 5(25), 2526 2533.

Nwaugo, V.O., Obikezie, S.O. and Etok, C.O. (2007b), Post operational quality effect of heavy metal mining in soil quality in Ishiagu, Ebonyi state. International journal of biotechnology. Allied Sci., 2(3), 242-246.

Nwaugo, V.O., Chima, G.N., Ekot, C.A. and Umeham, S.N. (2008a), Effect of cassava effluents on the physiochemical parameters of microbial flora of Nkissa River, Egbema Rivers State. International Journal Biotechnology and Allied Science. 1, 346 - 353

Okwute, L.O. and Isu, N.R. (2007a), the Environmental impact assessment of palm oil mill effluent (POME) on some physico-chemical parameters and total aerobic bioload of soil at a dump site in Anyiagba, Kogi State, Nigeria. African Journal of Agricultural Research, 2(12), $658-662$.

Olorunfemi, D.I., Obiaigwe, H. and Okieimen, F. (2009), Effect of Cassava Effluent on Germination of some cereals. Research Journal of Environmental Science, 1, 166 - 172.

Ray, A. (2006), Waste Management in developing Asia. Can trade and cooperation help? The Journal of Environmental and Development, 17, 13-106.

Sinsabaugh, R.L., Antibus, R.K. and Linkins, A.E. (1991), An enzyme approach to the analysis of microbial activity during plant letter decomposition. Agriculture, Ecosystem and Environment, 34, 43 - 54.

Skujins, J. (1976), Enzymes in soil. In: Mclern AD Peterson Gtt (eds). Soil Biochem. Vol. 1, Dekker, New York. $371-414$.

Speir, T.W. and Ross, D.S. (1978), Soil hsophatase and sulphase. In: Burns RH. (ed). Soil Enzymes, pp. 197 - 250, Academic Press, London, UK, p. 380.

Stevenson, F.J. (1986), The phosphorus cycle: Cycles of Soil. John Wiley. New York USA. Pp $285-230$.

Tabatabai, M.A. (1994), Soil enzymes. In: Weaver RW, Angle JS, Buttomley Ps (eds). Method of Soil Analysis, Part 2. Microbiological and Biochemical Property. SSSA Book series No. 5. Soil Science Society. AM. Madison, Wispp. 775 $-833$.

Tabatabai, M.A. and Bremner, J.M. (1969), Use of P-nitrophenyl phosphate for assay of soil phosphatase activities. Soil Biology and Biochemistry, 1, 307 - 312.

Tan, K.H. (1998), Principles of Soil Chemistry. Soil and Crop Science, 52, 383 - 390.

Torstensous, L.M. and Stenberg, B. (1998), Need of a strategy for evaluation of arable soil quality. Am. Bio., 27(1), 4-17.

Yang, Z., Liu, S., Zheng, D. and Fang, S. (2006), Effects of cadmium, zinc and lead on soil enzyme activities. Journal of Environmental Science, 18(6), 1135 - 1141. 